\title{
Role of Humic Substances and Compost Tea in Improvement of Endogenous Hormones Content, Flowering and Yield and its Components of Faba Bean (Vicia faba L.)
}

\author{
Osama A. M. Ali \\ Crop Science Dept., Faculty of Agriculture, Minufiya Univ., Egypt. \\ Corresponding author: os_ali2000@yahoo.com
}

\begin{abstract}
Production of faba bean in Egypt is still limited and fails to face the drastic increasing of local consumption due to decreasing the cultivated area and crop productivity. Two field experiments were carried out at the Experimental Farm of the Faculty of Agriculture, Minufiya University in Shebin El-Kom, Egypt to study the effect of organic substances (control, fulvic acid, humic acid and compost tea) applied either alone or in combinations on growth performance, leaf chemical constitutes, endogenous hormones content, flowering pattern, yield and quality of faba bean (Giza 3 cv.) during the two growing seasons of 2012/2013 and 2013/2014. Fulvic and humic acids were added at a rate of $4 \mathrm{~kg} \mathrm{fed}^{-1}$, while compost tea was added at a rate of $20 \mathrm{~L} \mathrm{fed}^{-1}$ during the first irrigation by soil drench method. The obtained results indicated that adding of organic substances either alone or in combinations has an effective role on enhancement of studied characters of plant growth (plant height, number of branches plant ${ }^{-1}$, leaf area and dry weights of leaves and stem plant ${ }^{-1}$ ); photosynthetic pigments (total chlorophyll content); endogenous phytohormones (IAA and $\mathrm{GA}_{3}$ ); leaf chemical constitutes (N, P, K, Zn; total soluble sugars and crude protein); flowering pattern (count and distribution of flowers and flowering duration); yield components (pods number plant ${ }^{-1}$, 100-seed weight, seed yield plant ${ }^{-1}$, seed yield $\mathrm{fed}^{-1}$ and straw yield $\mathrm{fed}^{-1}$ ) and seed chemical composition (protein and carbohydrates $\%$ and their yields) as compared to the untreated plants. Compost tea combined with humic acid surpassed the other organic substances for the produced highest values of abovementioned characters with the exception of leaf K content, total soluble sugars, total flowers number plant ${ }^{-1}$, flowering duration and seed carbohydrates $\%$ which were obtained by humic application. On the other hand, untreated plants have an increase in ABA content and total abscission percent. According to previous, the study recommends the importance of regular use of these organic substances to reduce the need for synthetic commercial fertilizers and the production of safe food through sustainable agricultural development systems.
\end{abstract}

Key words: Humic, Fulvic, Compost tea, Organic farming, Hormones, Yield, Faba bean.

\section{Introduction}

Faba bean (Vicia faba L.) is considered the main leguminous crop grown in Egypt. It is grown for dry seed and fresh consumption. It is an important legume crop due to its high nutritive value in both energy and protein contents. At the same time faba bean offers ecosystem services such as renewable inputs of nitrogen into crops and soil via biological ambient $\mathrm{N}_{2}$ fixation (Jensen et al., 2010). Production of faba bean in Egypt is still limited and fails to face the drastic increasing of local consumption, this is related to the cultivated area of faba bean in Egypt is relatively small and decreased dramatically in the last decade. According to the Ministry of Agriculture Statistics, faba bean showed decrease in both area and production. In 2007, its area was 215858 fed reached 183687 fed in 2009 and substantially decreased to 107621 fed in 2013. The total seed production was 336838 ton and decreased to 231990 ton and 157639 ton in the same respective years. The reduction in cultivated area and production may be due to 1) the competition between faba bean and other winter crops such as wheat and Egyptian clover; 2) the low and unstable yield of faba bean yearly. Unstable yield may be related to changing in flowers and pods abscission as well as climatic changes. Abscission is the term used to describe the process of natural separation of organs from the parent plant, lead to significant crop losses. Abscission is the culmination of changes in gene expression, which result in the loosening of adjacent cell walls within the zone and subsequent cell separation. It has been recognized that the balance between the plant hormones ethylene and auxin determine where, and when, separation takes place. (Taylor and Whitelaw, 2001). Increasing crop production is one of the most important targets of agricultural policy in Egypt. Increasing productivity largely depends on growing new promising cultivars and improving the cultural practices such as soil fertility by utilization of organic substances (organic amendments) which may help to solve this problem.

Organic fertilizers contain organic matter and include a diverse group of materials. Organic manures improve the behaviors of several elements in soils through that active group (fulvic and humic acids) which have the ability to retain the elements in complex and chelate form. Organic manures release the elements over a period of time and are broken down slowly by soil microorganisms (Ali et al., 2014). The majority of the nutrients in organic 
fertilizers are organically bound and slowly mineralized, so the potential for exceeding plant nutrient demands and associated environmental contamination is reduced relative to synthetic commercial fertilization (Stratton et al., 1995). Uses of organic materials are safe for human health and environmental elements.

Compost tea is liquid organic product that is rapidly gaining interest as a soil amendment with the hopes of improving soil quality and plant nutrition managing. The primary benefit of the tea will be a supply of soluble nutrients, which can be used as a liquid fertilizer. Also, the suppressive activity of different compost types toward several plant pathogens is well documented in the recent review of Litterick et al. (2004). Edwards et al. (2006) reported that transition from synthetic fertilization to compost tea may be feasible because much of the environmental pollution was happened in recent years. Also, tea produced from compost manure suppressed plant disease. Enteshari et al. (2012) mentioned that excessive use of fertilizers disturb the ecological balance and biological environment and also has caused many environmental hazards. However, using of organic compost reduces the negative effects of chemical fertilizer and improves water retention and enhances soil properties.

Humic substances are complex aggregates of brown to dark colored amorphous, which have originated during the decomposition of plant and animal residues by soil microorganisms, composts and water basins. These are natural organic polyelectrolytes present in the soil humus and stabilized soil organic matter. These molecules have ecological importance, as they intervene in the regulation of a large number of chemical and biological processes that occur in the natural ecosystems (Chen et al., 2004). Humic and fulvic acids are the main parts of humic substances and have a high value for soil fertility and plant growth in agricultural crops. It comprises $65-70 \%$ of the organic matter in soils. There is a world-wide acceptance that humic and fulvic acids are a vital part of their fertilizer program. It can be applied directly to the plant foliage in liquid form or to the soil in the form of granules or solution (Osman et al., 2013). Fulvic acid is soluble in strong acid solutions $(\mathrm{pH}=$ 1). An oxygen-to-carbon ratio greater than 0.5-1 indicates more acidic character than in other organic fractions of humic acid. Its structure is best characterized as a loose assembly of aromatic organic polymers with many carboxyl groups $(\mathrm{COOH})$ that release hydrogen ions, resulting in species that have electric charges at various sites on the ion. The major functional groups of humic acids include carboxyles, phenolic hydroxyls, alcoholic hydroxyls, ketones, and quinones (Russo and Berlyn, 1990). The mechanism of humic substances action in promoting plant growth is not completely known, but several explanations have been given by some authors (Biondi et al., 1994; Chen et al., 2004 and Khaled and Fawy, 2011) as increasing of cell membrane permeability, oxygen uptake, respiration and photosynthesis, enzymatic activities, phosphorus uptake, root and cell elongation, ions transport and soil microorganisms.

The objectives of the present research are to determine the influence of different organic substances applied either alone or in combinations for improving the endogenous hormones content, flowering, yield and its components and quality of faba bean.

\section{Materials and Methods}

Two field experiments were carried out at the Experimental Farm of the Faculty of Agriculture, Minufiya University in Shebin El-Kom, Egypt (latitude $30^{\circ} 31^{\prime} 39^{\prime \prime} \mathrm{N}$, longitude $31^{\circ} 04^{\prime} 03^{\prime \prime} \mathrm{E}$ ) to evaluate the effect of different organic substances applied either alone or in combinations to improve the growth performance, endogenous promoter hormones content, leaf chemical constituents, flowering pattern, yield and is components and quality of faba bean (Giza $3 \mathrm{cv}$.) during the two growing seasons of 2012/2013 and 2013/2014. Each experiment included six treatments as follows:

1- Control (untreated plants)

2- Compost tea (CT)

3- Fulvic acid (FA)

4- Humic acid (HA)

5- Compost tea + Fulvic acid $(\mathrm{CT}+\mathrm{FA})$

6- Compost tea + Humic acid (CT+ HA)

The Treatments were arranged in a randomized complete bloke design with four replications. Applying the organic substances after preparing using soil drench method as an organic amendment

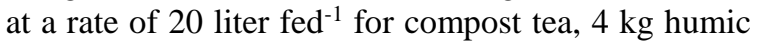
$\mathrm{fed}^{-1}$ and $4 \mathrm{~kg}$ fulvic fed ${ }^{-1}$ during the first irrigation (30 days after sowing "DAS"). Soil samples were randomly taken from the experimental field before planting at $30 \mathrm{~cm}$ depth. The mechanical and chemical analysis of the soil was according to Jackson (1973) and Chapman and Pratt (1978) are presented in Table (1).

Table 1. Mechanical and chemical properties of the experimental site.

\begin{tabular}{lllllllllll}
\hline \multirow{2}{*}{ Properties } & \multirow{2}{*}{ Texture class } & \multirow{2}{*}{$\mathrm{pH}$} & \multirow{2}{*}{$\begin{array}{l}\text { E.C. } \\
\mathrm{ds} / \mathrm{m}\end{array}$} & \multirow{2}{*}{\begin{tabular}{l} 
O.M. \\
\cline { 7 - 12 }
\end{tabular}} & & & & \multicolumn{6}{c}{ Available nutrients (ppm) } \\
\hline $2012 / 2013$ & Clay loam & 7.4 & 0.73 & 1.7 & 30.2 & 9.2 & 301.3 & 4.57 & 1.06 & 2.81 \\
$2013 / 2014$ & Clay loam & 7.3 & 0.81 & 2.0 & 31.6 & 8.9 & 332.5 & 4.95 & 0.91 & 3.47 \\
\hline
\end{tabular}




\section{Organic substances preparation}

Compost used in this study was obtained from El-Khalil Factory for Compost at El-Khatatba province, Minufiya Governorate, Egypt. Compost tea was prepared by brewing compost and tap water in the ratio of 1:5 w/v (compost: water) using brewing tank fitted with an aquarium pump for continuous aeration. Aeration during the brewing process distinguishes compost tea from other compost extracts, and is important considering the goal of increasing aerobic microorganisms because that oxygen is necessary for bacterial respiration that drives the composting process. Microbial substrates of beneficial microorganisms were incorporated with the compost and subjected to brewing period of 7 days at $25^{\circ} \mathrm{C}$ (Naidu et al., 2010). The end product was filtered to remove large debris and the liquid extract used immediately. Compost tea properties are presented in Table (2). Humic substances used are produced by Humintech® Company in Germany, Am Pösenberg 9-13, 41517 Grevenbroich. Humic substances were dissolved in distillated water to prepare solutions of these substances. Potassium humate $80 \%$ was used as a source of humic acid. Elementary composition of humic acid and fulvic acid are presented in Table (2).

Table 2. Properties of organic substances used.

\begin{tabular}{|c|c|c|c|c|c|}
\hline \multicolumn{2}{|l|}{ Compost tea } & \multicolumn{2}{|c|}{ Fulvic acid } & \multicolumn{2}{|c|}{ Humic acid } \\
\hline pH & 7.4 & Appearance & brown powder & Appearance & Black powder \\
\hline $\mathrm{EC} \quad\left(\mathrm{ds} \mathrm{m}^{-1}\right)$ & 1.4 & solubility & Water and acidic & solubility & Water and alkaline \\
\hline $\mathbf{N} \quad\left(m g \mathbf{L}^{-1}\right)$ & 98.6 & pH & 4.00 & pH & 9.00 \\
\hline $\mathrm{NO}_{3}-\mathrm{N}\left(\mathrm{mg} \mathrm{L}^{-1}\right)$ & 96.9 & $\mathrm{C} \%$ & 40.1 & $\mathrm{C} \%$ & 49.6 \\
\hline $\mathrm{NH}_{4}-\mathrm{N}\left(\mathrm{mg} \mathrm{L}^{-1}\right)$ & 1.7 & N\% & 0.67 & $\mathbf{N \%}$ & 1.85 \\
\hline $\mathbf{P} \quad\left(\mathbf{m g ~ L}^{-1}\right)$ & 3.6 & $\mathrm{H} \%$ & 3.57 & H\% & 7.15 \\
\hline $\mathrm{K} \quad\left(\mathbf{m g ~ L ^ { - 1 }}\right)$ & 37.2 & O\% & 55.0 & $\mathbf{0 \%}$ & 37.3 \\
\hline $\mathrm{Ca} \quad\left(\mathrm{mg} \mathrm{L}^{-1}\right)$ & 104.3 & $\mathrm{~S} \%$ & 0.66 & S\% & 4.10 \\
\hline $\operatorname{Mg}\left(\mathrm{mg} \mathrm{L}^{-1}\right)$ & 50.1 & & & & \\
\hline Fe $\left(m g L^{-1}\right)$ & 14.3 & & & & \\
\hline $\mathrm{Zn} \quad\left(\mathrm{mg} \mathrm{L}^{-1}\right)$ & 4.6 & & & & \\
\hline $\operatorname{Mn}\left(\mathrm{mg} \mathrm{L}^{-1}\right)$ & 3.5 & & & & \\
\hline $\mathrm{Cu} \quad\left(\mathrm{mg} \mathrm{L}^{-1}\right)$ & 1.2 & & & & \\
\hline Bacteria $\left(\log _{10}\right.$ cell $\left.\mathrm{ml}^{-1}\right)$ & 7.2 & & & & \\
\hline Fungi $\quad\left(\log _{10}\right.$ cell $\left.\mathrm{ml}^{-1}\right)$ & 5.3 & & & & \\
\hline Actinomycetes $\left(\log _{10}\right.$ cell ml-1) & 6.2 & & & & \\
\hline
\end{tabular}

\section{Crop management under organic farming}

The experimental field was ploughed twice, harrowed and leveled after maize harvesting to prepare the seed bed. Soil was ridged into furrows 60 $\mathrm{cm}$ width and divided plots. Each experimental plot including seven furrows with $3.5 \mathrm{~m}$ long. The plot area was $14.7 \mathrm{~m}^{2}$. Seeds were sown on $11^{\text {th }}$ and $14^{\text {th }}$ October in first and second seasons, respectively. Twenty five days after sowing "DAS", plants were thinned to two plants hill ${ }^{-1}$ on one side of the furrow and one plant hill $^{-1}$ on the other side of the furrow with $20 \mathrm{~cm}$ between hills to produce 105000 plants fed $^{-1}$.

Faba bean seeds were treated before sowing with Clean Root contains Bacillus subtilis $\left(30 \times 10^{6}\right.$ c.f.u. $/ 1 \mathrm{~g})$. This inoculant prepared by the Central Laboratory of Organic Agriculture (CLOA), Agricultural Research Center, Egypt. Seeds were wetted using Arabic gum solution and mixed with Clean Root at a rate of $10 \mathrm{~g} / 1 \mathrm{~kg}$ of seeds. Treated seeds were left to dry in shadow then sown directly.

In all experimental plots, faba bean plants were treated with Anti-insect produced by CLOA as a biocide contains Beauveria bassiana to protect plants against sucking insects (aphids and white fly). Antiinsect was used at a rate of 1 liter/200 liter of water. The Anti-insect was sprayed three times, the first one was done at 30 DAS and repeated every 15 days.
Also, plants were treated against fungal diseases by using the biological preparation (Blight stop) contains Trichoderma harzianum $\left(30 \times 10^{6}\right.$ c.f.u / ml) produced by CLOA. The Blight stop was used at a rate of 1liter/200 liter of water. The treatment was sprayed at 50 DAS and repeated three times with 15 days intervals.

All of the required cultural practices, (other than treatment variables), were performed as recommended for the area according to organic farming rules.

\section{Plant measurements:}

- Vegetative growth and chlorophyll

At 75 days after sowing, ten guarded plants from each plot were taken randomly to estimate plant height, numbers of branches plant ${ }^{-1}$, leaf area plant ${ }^{-1}$ and leaves and stem dry weights plant ${ }^{-1}$. Total chlorophyll content in leaves was determined spectrophotometry according to Wettstein (1957).

\section{- Endogenous phytohormones}

At 80 DAS, sample of $20 \mathrm{~g}$ fresh material from the apices and fully expanded young leaves of plants were homogenized with ice-cold absolute methanol in a blender and stored at $3{ }^{\circ} \mathrm{C}$ for about $24 \mathrm{hr}$. The alcohol was filtered and two subsequent extractions were made with $80 \%$ ice-cold methanol. The combined alcoholic extracts were evaporated to the 
aqueous phase at a temperature not exceeding $30{ }^{\circ} \mathrm{C}$ (Badr et al., 1971). The aqueous phase was adjusted to $\mathrm{pH} 8.2$ with $1 \mathrm{~N} \mathrm{KOH}$ and distribute three times against equal volumes of petroleum ether to remove the lipids, pigments and other undesirable substances. The petroleum ether phase was discarded. Separation of gibberellin $\left(\mathrm{GA}_{3}\right)$, auxin (IAA) and abscisic acid (ABA) were carried out according to Hiraja et al. (1972) and Asch et al. (2001). Endogenous phytohormones of the extracted samples were quantitatively determined in the second season using High- Performance Liquid Chromatography (HPLC). Hormones were detected by their absorption at $255 \mathrm{~nm}$ and the peak area of the samples were compared to the corresponding peak areas of standard solutions containing known concentrations.

\section{- Leaf chemical constituents}

Mineral content were measured in dried leaves at 90 DAS. Nitrogen was determined using the micro Kjeldahl method as described by AOAC (2000), Phosphorus was determined by the vanadomolybdate phosphoric acid yellow color method outlined by Jackson (1973). Potassium was estimated using flame photometer method described by Chapman and Pratt (1978). Zinc was determined using the Atomic Absorption method (Steponënienë et al., 2003).

Total soluble sugars (TSS) were extracted by overnight submersion of dry tissue in $10 \mathrm{ml}$ of $80 \%$ $(\mathrm{v} / \mathrm{v})$ ethanol at $25^{\circ} \mathrm{C}$ with periodic shaking, and centrifuged at $600 \mathrm{rpm}$. The TSS were analyzed by reacting of $0.1 \mathrm{ml}$ of ethanolic extract with $3.0 \mathrm{ml}$ freshly prepared anthrone $(150 \mathrm{mg}$ anthrone +100 $\mathrm{ml} 72 \% \mathrm{H}_{2} \mathrm{SO}_{4}$ ) in boiling water bath for ten minutes and reading the cooled samples at $625 \mathrm{~nm}$ using Spectrophotometer (Homme et al., 1992).

\section{- Flowering pattern}

Since commence of flowering, six guarded plants of three successive hills from second furrow were labeled and marked at random in each experimental plot. Numbers of flowers were measured during the flowering period of 2 days intervals from the beginning of blooming of first flower until the end of flowering period to determine the following characteristics:

1- Number of flowers/plant produced was counted each 10 days interval.

2- Total abscission /plant $(\%)=$

[(number of flowers/plant- number of mature pods/plant)/ number of flowers/plant] x 100

3- Flowering duration (days) is an approximate length of the flowering, which is the differences between the first flowering date and the end flowering date.

\section{- Yield and its components}

At harvest, ten guarded plants were taken randomly to determine number of pods plant ${ }^{-1}$, number of seeds pod $^{-1}$, seed index and seed yield plant $^{-1}$. Seed and straw yields of inner three furrows were determined and estimated in $\mathrm{kg} \mathrm{fed}^{-1}$.

\section{- Seed chemical composition}

At maturity, seed samples were dried in air-oven at $70^{\circ} \mathrm{C}$ to constant weight before grinding with a mill to pass through a $0.5 \mathrm{~mm}$ sieve. The samples were chemically analyzed to determine their contents of protein and carbohydrates. Protein percentage was determined by the micro Kjeldahl method (AOAC, 2000). Total carbohydrates was measured according to the methods described by Dubois et al. (1956). Protein and carbohydrate yields were determined by multiplying seed yield $\mathrm{fed}^{-1}$ by seed protein and carbohydrates percentages on dry basis of the obtained seeds.

\section{Statistical analysis}

All measurements data during the two seasons in this study were analyzed according the methods described by Snedecor and Cochran (1980). Duncan's multiple range test (Duncan, 1955) was used to compare between the treatments mean at $5 \%$ probability. Statistical analysis was done using the CoStat package program, version 6.311 (Cohort software, USA).

\section{Results and Discussion}

\section{Growth and chlorophyll}

Values of plant growth and total chlorophyll content as influenced by humic substances (humic acid and fulvic acid) and compost tea are given in Table (3). The result demonstrated that the application of humic substances and/or compost tea caused a significant enhancement in growth parameters during both seasons. The application of compost tea + humic acid (CT + HA) exhibited the highest plant height, branches number, leaf area, leaves and stem dry weights and total chlorophyll followed by sole application of humic. Compost is generally has higher concentrations of plant available nutrients $\left(\mathrm{NO}_{3}\right.$ and $\mathrm{NH}_{4}$ - exchangeable $\mathrm{Ca}, \mathrm{P}$ and soluble $\mathrm{K}$ ) and significantly larger and more diverse microbial populations (Tognetti et al., 2005). Increased overall root development with the application of compost tea and humic acid may have contributed to better nutrient uptake and increased leaf area (Pant et al., 2012 and Büyükkeskin et al., 2015). Leaf area plays an important role in light interception, photosynthesis, water and nutrient use and dry matter production. Larger leaf area of treated plants with organic amendments could have been linked to increase plant dry weight. Also, plant growth improves by the ability of the plants to uptake and receives more nutrients. Humic acid and compost tea are especially beneficial in freeing up nutrients in the soil so that they made its available to the plants as needed (Khaled and Fawy, 2011 and El- 
Gizawy et al., 2013). This reflects increase in plant growth and photosynthesis. Various publications have indicated the importance of humic acid (Ahmed et al., 2010) as well as compost tea and humic acid (El-Sayed et al., 2015) on improving plant growth parameters and chlorophyll content.

Table 3. Faba bean growth and chlorophyll content as influenced by organic substances application at 75 DAS.

\begin{tabular}{|c|c|c|c|c|c|c|}
\hline Organic substances & $\begin{array}{c}\text { Plant height } \\
(\mathrm{cm})\end{array}$ & $\begin{array}{c}\text { Branches } \\
\left(\text { No. plant }{ }^{-1}\right)\end{array}$ & $\begin{array}{c}\text { Leaf area } \\
\left(\mathrm{cm}^{2} \text { plant }^{-1}\right)\end{array}$ & $\begin{array}{c}\text { Leaves dry } \\
\text { weight } \\
\left.\text { (g. } \text { plant }^{-1}\right) \\
\end{array}$ & $\begin{array}{c}\text { Stem dry } \\
\text { weight } \\
\left(\text { g. } \text { plant }^{-1}\right) \\
\end{array}$ & $\begin{array}{c}\text { Total } \\
\text { chlorophyll (mg. } \\
\mathrm{g}^{-1} \text { D.W.) } \\
\end{array}$ \\
\hline & \multicolumn{6}{|c|}{$2012 / 2013$} \\
\hline Control & $82.65 \mathrm{~b}$ & $3.08 \mathrm{~b}$ & $2031.21 \mathrm{~b}$ & $7.13 \mathrm{c}$ & $9.13 \mathrm{~b}$ & $7.32 \mathrm{c}$ \\
\hline Compost tea (CT) & $90.02 a$ & $3.68 \mathrm{ab}$ & 2264.68 a & 8.84 bc & $11.25 \mathrm{ab}$ & $9.21 \mathrm{ab}$ \\
\hline Fulvic acid (FA) & $83.50 \mathrm{~b}$ & $3.58 \mathrm{ab}$ & 2190.85 a & $8.25 \mathrm{bc}$ & $10.62 \mathrm{ab}$ & $8.92 \mathrm{ab}$ \\
\hline Humic acid (HA) & 88.14 ab & $4.17 \mathrm{a}$ & 2294.67 a & $9.64 \mathrm{ab}$ & $12.12 \mathrm{a}$ & $9.35 \mathrm{ab}$ \\
\hline $\mathbf{C T}+\mathbf{F A}$ & $87.31 \mathrm{ab}$ & $3.90 \mathrm{ab}$ & 2251.72 a & $10.18 \mathrm{ab}$ & $12.40 \mathrm{a}$ & $8.40 \mathrm{bc}$ \\
\hline \multirow[t]{2}{*}{$\mathbf{C T}+\mathbf{H A}$} & $91.54 \mathrm{a}$ & $4.25 \mathrm{a}$ & 2321.19 a & $11.42 \mathrm{a}$ & 12.89 a & 10.07 a \\
\hline & \multicolumn{6}{|c|}{$2013 / 2014$} \\
\hline Control & $87.23 \mathrm{c}$ & $3.00 \mathrm{~b}$ & $2110.42 \mathrm{c}$ & $8.06 \mathrm{~d}$ & $9.94 \mathrm{~b}$ & $6.45 \mathrm{c}$ \\
\hline Compost tea (CT) & 93.24 abc & $3.75 \mathrm{ab}$ & $2289.18 \mathrm{~b}$ & 9.72 bc & $11.68 \mathrm{ab}$ & $9.15 \mathrm{ab}$ \\
\hline Fulvic acid (FA) & 89.97 bc & $3.25 \mathrm{ab}$ & 2231.15 b & $8.82 \mathrm{~cd}$ & $10.82 \mathrm{ab}$ & $8.36 \mathrm{~b}$ \\
\hline Humic acid (HA) & $94.11 \mathrm{ab}$ & $3.90 \mathrm{ab}$ & $2302.88 \mathrm{~b}$ & $10.51 \mathrm{ab}$ & $12.93 \mathrm{a}$ & $9.07 \mathbf{a b}$ \\
\hline $\mathbf{C T}+\mathbf{F A}$ & $93.48 \mathrm{ab}$ & $3.43 \mathrm{ab}$ & 2246.64 b & 9.97 bc & $13.11 \mathrm{a}$ & $8.57 \mathrm{~b}$ \\
\hline $\mathbf{C T}+\mathbf{H A}$ & $98.81 \mathrm{a}$ & $4.50 \mathrm{a}$ & 2418.25 a & 11.89 a & $13.65 \mathrm{a}$ & $9.87 \mathrm{a}$ \\
\hline
\end{tabular}

\section{Endogenous phytohormones}

Data illustrated in Fig (1) indicated that organic substances application caused remarkable increase in $\mathrm{GA}_{3}$ and IAA content, while ABA content was decreased as compared to untreated plants. Auxin content showed an opposite trend to that of abscisic acid. Combined application of compost tea and humic acid resulted in increasing hormones growth promoters in leaves at $80 \mathrm{DAS}$, at the same time caused remarkable reductions in the growth inhibitor ABA. Endogenous hormones control the different physiological processes, directly or indirectly, through various metabolic pathways.

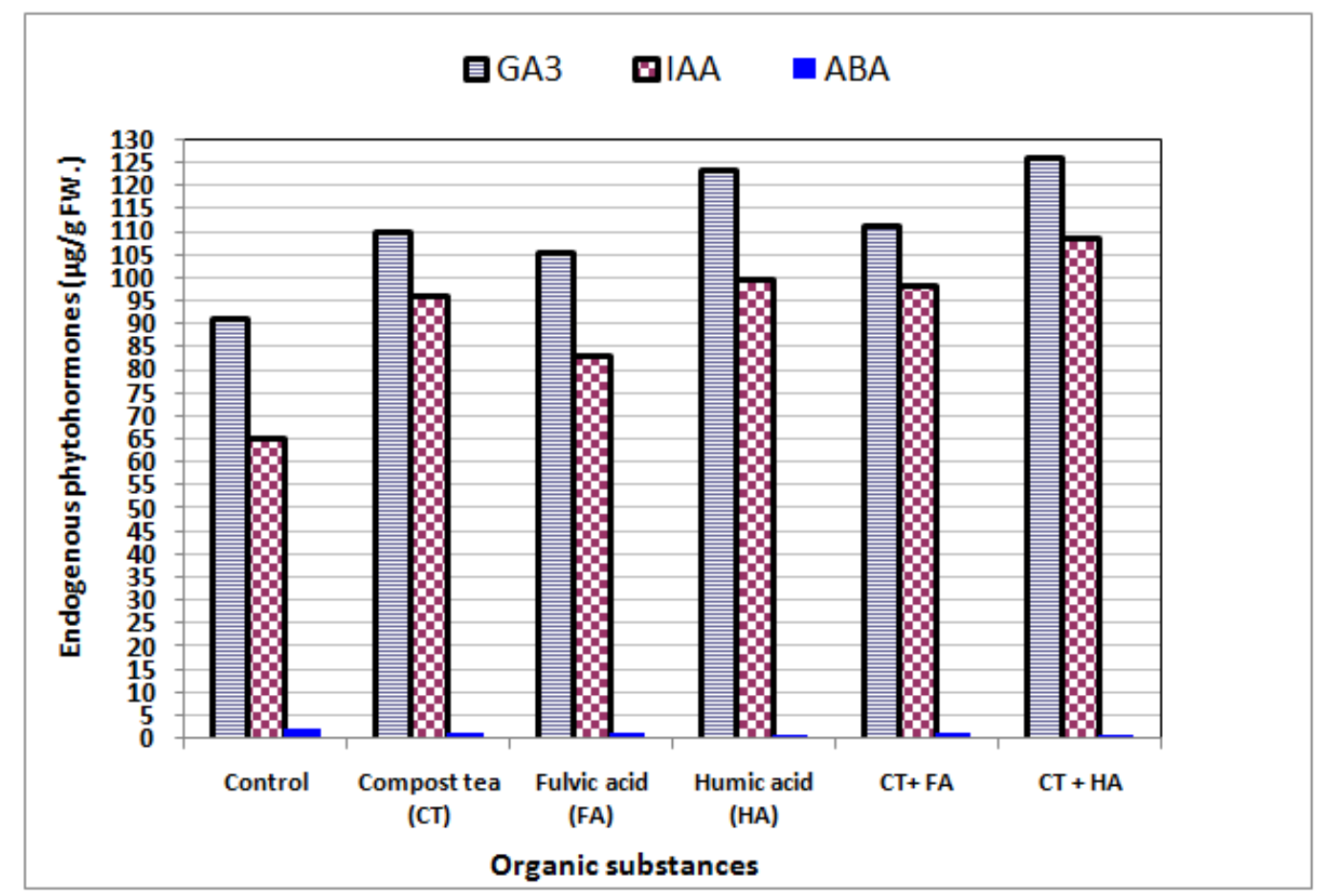

Fig 1. Endogenous phytohormones of faba bean leaves at 80 DAS as influenced by organic substances application during 2013/2014 season. 
Humic acids improve plant physiological processes by enhancing the availability of major and minor nutrients as well as enhancing the vitamins, amino acids, and also auxin and cytokinin contents of the plants (Vanitha and Mohandass, 2014). Organic substances can alter the hormonal status of plant and exert influence over its growth as mentioned by Abbas (2013) who found that humic acid application at a rate of $20 \mathrm{~g} \mathrm{~L}^{-1}$ increased the levels of endogenous IAA and $\mathrm{GA}_{3}$ in treating faba bean plant shoots as compared to control, while ABA content decreased. These results that were obtained may be due to the potential effects of enhancing enzymes activity.

\section{Leaf chemical constituents}

The obtained results in Table (4) indicated that utilization of organic substances either separately or mixed caused a significant increase in nutrients content, total soluble sugars and crude protein compared to untreated plants. Applying of compost tea + humic acid to soil increases the rate of absorption of $\mathrm{N}, \mathrm{P}$ and $\mathrm{Zn}$ ions of root surfaces and their penetration into the cells of the plant tissue. Humic acid caused an increase in potassium percentage in leaves which had an important role in effect and synthesis of carbohydrates substances in leaves and its translocation (Sarhan et al., 2011). Organic amendments can improve nutrients concentrations in plant tissues by increasing both fresh and dry weights and development of roots, enhancement of soil organisms activity and preventing nutrient ions from leaching (Akinci et al., 2009 and Pant et al., 2011). Humic substances can increase the solubility of insoluble P-compounds in soil with its chelation capacity, and chelated metals are also available to plants with exchange (Tan, 2003). Further, the humic acid is known to form chelates with micronutrients and thus it improves translocation of the nutrient cations within the plant system. Generally, the enhancement of chemical constituent contents may be considered as a direct result for high rates of photosynthesis that was obtained through the large photosynthetic area and high content of photosynthetic pigments (Table 3 ). Other researchers reported the importance of organic amendment such as fulvic acid (Navarrete et al., 2004), compost tea (El-Gizawy et al., 2013), humic acid (Ahmed et al., 2010 and Büyükkeskin et al., 2015) as well as compost tea and humic acid (Khafaga et al., 2014) on enhancing chemical constituent contents of treated plants.

Table 4. Chemical constituents of faba bean leaves at 90 DAS as influenced by organic substances application.

\begin{tabular}{|c|c|c|c|c|c|c|}
\hline \multirow[t]{2}{*}{ Organic substances } & $\begin{array}{c}\mathrm{N} \\
\left(\mathrm{mg} \mathrm{g}^{-1} \text { D.W. }\right)\end{array}$ & $\begin{array}{c}\mathrm{P} \\
\left(\mathrm{mg} \mathrm{g}^{-1} \text { D.W. }\right)\end{array}$ & $\begin{array}{c}\mathrm{K} \\
\left(\mathrm{mg} \mathrm{g}^{-1} \text { D.W.) }\right.\end{array}$ & $\begin{array}{c}\mathrm{Zn} \\
\left(\mu \mathrm{g} \mathrm{g}^{-1} \text { D.W. }\right)\end{array}$ & $\begin{array}{c}\text { Total soluble } \\
\text { sugars } \\
\text { (mg g-1 D.W.) } \\
\end{array}$ & $\begin{array}{l}\text { Crude protein } \\
\left(\mathrm{mg} \mathrm{g}^{-1} \text { D.W. }\right)\end{array}$ \\
\hline & \multicolumn{6}{|c|}{$2012 / 2013$} \\
\hline Control & $29.53 b$ & $3.28 \mathrm{c}$ & $21.36 \mathrm{c}$ & $20.31 \mathrm{~b}$ & $17.51 \mathrm{~b}$ & $184.56 \mathrm{~d}$ \\
\hline Compost tea (CT) & $33.68 \mathrm{a}$ & $3.64 \mathrm{bc}$ & $23.97 \mathrm{ab}$ & $23.54 \mathrm{ab}$ & $20.31 \mathrm{a}$ & $210.50 \mathrm{~b}$ \\
\hline Fulvic acid (FA) & $31.54 \mathrm{ab}$ & $3.47 \mathrm{bc}$ & $22.45 \mathrm{~b}$ & $21.24 \mathrm{~b}$ & $19.74 \mathrm{ab}$ & $197.13 \mathrm{c}$ \\
\hline Humic acid (HA) & $33.24 \mathrm{a}$ & $3.92 \mathrm{ab}$ & $26.15 \mathrm{a}$ & $23.28 \mathrm{ab}$ & $22.54 \mathrm{a}$ & $207.75 \mathrm{~b}$ \\
\hline $\mathrm{CT}+\mathrm{FA}$ & $33.47 \mathrm{a}$ & $3.68 \mathrm{abc}$ & $23.58 \mathrm{ab}$ & $23.42 \mathrm{ab}$ & $21.14 \mathrm{a}$ & $209.19 b$ \\
\hline \multirow[t]{2}{*}{$\mathrm{CT}+\mathrm{HA}$} & $34.84 \mathrm{a}$ & $4.12 \mathrm{a}$ & $24.64 \mathrm{ab}$ & $25.44 \mathrm{a}$ & $21.64 \mathrm{a}$ & $217.75 \mathrm{a}$ \\
\hline & \multicolumn{6}{|c|}{2013 / 2014} \\
\hline Control & $30.11 \mathrm{c}$ & $3.14 \mathrm{c}$ & $21.11 \mathrm{~b}$ & $21.16 \mathrm{~b}$ & $16.24 \mathrm{c}$ & $188.19 \mathrm{e}$ \\
\hline Compost tea (CT) & $33.84 \mathrm{ab}$ & $3.51 \mathrm{abc}$ & $25.04 \mathrm{a}$ & $22.64 \mathrm{ab}$ & $19.94 \mathrm{ab}$ & $211.50 \mathrm{~b}$ \\
\hline Fulvic acid (FA) & $31.87 \mathrm{bc}$ & $3.25 \mathrm{c}$ & $23.54 \mathrm{ab}$ & $22.05 \mathrm{ab}$ & $18.11 \mathrm{bc}$ & $199.19 \mathrm{~d}$ \\
\hline Humic acid (HA) & $33.31 \mathrm{ab}$ & $3.84 \mathrm{ab}$ & $25.74 \mathrm{a}$ & $23.21 \mathrm{ab}$ & $21.66 \mathrm{a}$ & $208.19 \mathrm{c}$ \\
\hline $\mathrm{CT}+\mathrm{FA}$ & $32.94 \mathrm{ab}$ & $3.47 \mathrm{bc}$ & $24.98 \mathrm{a}$ & $22.14 \mathrm{ab}$ & $20.23 \mathrm{ab}$ & $205.88 \mathrm{c}$ \\
\hline $\mathrm{CT}+\mathrm{HA}$ & $35.24 \mathrm{a}$ & $3.91 \mathrm{a}$ & $25.18 \mathrm{a}$ & $24.84 \mathrm{a}$ & $21.27 \mathrm{a}$ & $220.25 \mathrm{a}$ \\
\hline
\end{tabular}

\section{Flowering pattern}

Flowering patterns are defined by the frequency and duration of flowering. Cumulative number of flowers produced every ten days and their distribution during different development stages of faba bean plants as affected by organic substances are shown in Table (5). The data show that the plants treated with humic acid gave its first flowers at about 51 and 53 DAS while untreated plants gave its first flower at about 55 and 54 DAS in the first and second seasons, respectively. Across these dataset, flowering duration ranged between 68.25 to 74.25 and 63.0 to 73.5 days in the first and second seasons, respectively. 
Table 5. Changes in flowering pattern of faba bean plants as influenced by organic substances application.

\begin{tabular}{|c|c|c|c|c|c|c|c|c|c|c|c|}
\hline \multirow{3}{*}{$\begin{array}{c}\text { Organic } \\
\text { substances }\end{array}$} & \multicolumn{8}{|c|}{ Cumulative flowers per plant each 10 days intervals } & \multirow{2}{*}{$\begin{array}{c}\text { Flowering } \\
\text { duration } \\
\text { (days) }\end{array}$} & \multirow{2}{*}{$\begin{array}{l}\text { Total flowers } \\
\left(\text { No. plant }{ }^{-1}\right)\end{array}$} & \multirow{2}{*}{$\begin{array}{c}\text { Total abscission } \\
(\%)\end{array}$} \\
\hline & $\begin{array}{l}\text { 51-60 } \\
\text { DAS }\end{array}$ & $\begin{array}{l}\text { 61-70 } \\
\text { DAS }\end{array}$ & $\begin{array}{c}71-80 \\
\text { DAS }\end{array}$ & $\begin{array}{c}\text { 81-90 } \\
\text { DAS }\end{array}$ & $\begin{array}{c}\text { 91-100 } \\
\text { DAS }\end{array}$ & $\begin{array}{c}\text { 101-110 } \\
\text { DAS }\end{array}$ & $\begin{array}{c}\text { 111-120 } \\
\text { DAS }\end{array}$ & $\begin{array}{c}\text { 121-130 } \\
\text { DAS }\end{array}$ & & & \\
\hline & \multicolumn{11}{|c|}{$2012 / 2013$} \\
\hline Control & $7.25 \mathrm{c}$ & $14.75 \mathrm{c}$ & $26.08 \mathrm{c}$ & 30.08 b & 34.92 bc & 19.67 bc & $10.58 \mathrm{bc}$ & $2.25 \mathrm{~b}$ & $68.25 \mathrm{~d}$ & $145.58 \mathrm{~d}$ & 88.15 a \\
\hline Compost tea $(\mathrm{CT})$ & $11.42 \mathrm{a}$ & $19.75 \mathrm{ab}$ & 33.17 a & $31.58 \mathrm{a}$ & $34.25 \mathrm{c}$ & $21.5 \mathrm{bc}$ & 11.42 bc & $4.17 \mathrm{ab}$ & $73.50 \mathrm{~b}$ & $167.26 \mathrm{ab}$ & 87.19 ab \\
\hline Fulvic acid (FA) & $9.50 \mathrm{~b}$ & $17.92 \mathrm{~b}$ & $29.75 \mathrm{~b}$ & $26.83 \mathrm{c}$ & $35.67 \mathrm{~b}$ & $19.08 \mathrm{c}$ & $9.50 \mathrm{bc}$ & $3.67 \mathbf{a b}$ & $71.25 \mathrm{c}$ & $151.92 \mathrm{c}$ & 86.67 bc \\
\hline Humic acid (HA) & $12.08 \mathrm{a}$ & $15.05 \mathrm{c}$ & $32.5 \mathrm{a}$ & $32.25 \mathrm{a}$ & 38.67 a & $22.08 \mathrm{~b}$ & $8.92 \mathrm{c}$ & $6.75 \mathrm{a}$ & $76.75 \mathrm{a}$ & $168.30 \mathrm{a}$ & 86.88 bc \\
\hline $\mathbf{C T}+\mathbf{F A}$ & $11.75 \mathrm{a}$ & 20.5 a & $23.25 \mathrm{~d}$ & $31.42 \mathrm{a}$ & 35.08 bc & 26.42 a & $12.08 \mathrm{ab}$ & $5.08 \mathrm{ab}$ & $73.50 \mathrm{~b}$ & $165.58 \mathrm{~b}$ & 86.92 bc \\
\hline \multirow[t]{2}{*}{$\mathbf{C T}+\mathbf{H A}$} & $10.75 a b$ & $18.50 \mathrm{~b}$ & $33.42 \mathrm{a}$ & $32.25 \mathrm{a}$ & $31.67 \mathrm{~d}$ & 20.75 bc & $14.24 \mathrm{a}$ & $6.08 \mathrm{a}$ & $74.25 \mathrm{~b}$ & $167.66 \mathrm{a}$ & $85.94 \mathrm{c}$ \\
\hline & \multicolumn{11}{|c|}{$2013 / 2014$} \\
\hline Control & $8.08 \mathrm{c}$ & $19.25 \mathrm{~b}$ & 23.42 b & $27.75 \mathrm{ab}$ & $24.25 \mathrm{~b}$ & $18.08 \mathrm{~b}$ & $10.58 \mathrm{~b}$ & $5.17 \mathrm{a}$ & $63.00 \mathrm{e}$ & $136.58 \mathrm{~d}$ & 87.92 a \\
\hline Compost tea (CT) & $9.67 \mathrm{bc}$ & $21.08 \mathrm{~b}$ & $23.67 \mathrm{~b}$ & $29.42 \mathrm{a}$ & 28.42 a & 24.16 a & $13.75 \mathrm{ab}$ & $5.67 \mathrm{a}$ & $69.75 \mathrm{~cd}$ & $155.84 \mathrm{~b}$ & 87.06 a \\
\hline Fulvic acid (FA) & $11.92 \mathrm{ab}$ & $20.67 \mathrm{~b}$ & $25.16 \mathrm{~b}$ & 24.33 bc & $22.67 \mathrm{~b}$ & $18.67 \mathrm{~b}$ & $13.59 \mathrm{ab}$ & 5.17 a & $68.25 \mathrm{~d}$ & $142.18 \mathrm{~cd}$ & 85.99 bc \\
\hline Humic acid (HA) & 12.17 a & 20.17 b & $34.25 \mathrm{a}$ & $30.58 \mathrm{a}$ & 29.5 a & $19.67 \mathrm{~b}$ & $10.33 \mathrm{~b}$ & $9.00 \mathrm{a}$ & $74.25 \mathrm{a}$ & 165.67 a & 86.97 ab \\
\hline $\mathbf{C T}+\mathbf{F A}$ & 11.17 ab & $14.5 \mathrm{c}$ & $16.25 \mathrm{c}$ & $20.42 \mathrm{c}$ & 30.92 a & $26.58 \mathrm{a}$ & $12.50 \mathrm{ab}$ & $7.25 \mathrm{a}$ & 71.00 bc & 139.59 a & 85.62 c \\
\hline $\mathbf{C T}+\mathbf{H A}$ & $9.42 \mathrm{bc}$ & $25.22 \mathrm{a}$ & $21.25 \mathrm{~b}$ & $25.58 \mathrm{ab}$ & 23.17 b & $18.67 \mathrm{~b}$ & $15.42 \mathrm{a}$ & $9.25 \mathrm{a}$ & $72.50 \mathrm{ab}$ & $147.98 \mathrm{c}$ & $85.03 \mathrm{c}$ \\
\hline
\end{tabular}


It can be noticed that plants treated with humic had flowering period longer than other untreated plants, followed by compost tea + humic treatment in both seasons. Faba bean plants generally produced their flowers during three periods. The effective period extended from 81 to 100 DAS. Application of humic substances and compost tea had a positive effect on the production and distribution of the flowers/plant. The response has differed from interval to another during the two seasons. Overall, the highest total flowers numbers (168.3 and 165.67 in the respective seasons) produced along the flowering period which were obtained when the plants received humic acid. The organic materials may comprise compounds that serve as substrates for the synthesis of biologically active substances including hormone-like substances (Nardi et al., 2002). Flowering distribution have been explained and supported by proving that humic fractions have a high hormonal activity which lead to increase flowers number. The beneficial effects of humic and/or compost tea on flowering patterns may be attributed to their role in increasing plant growth hormones (Fig 1), nutrients absorption and soluble sugars content (Table 4) which influence plant metabolism and enzymes activities (El-Gizawy et al., 2013), which in turn encourage flower formation.

Concerning total abscission (flowers and pods), the data of the same table declared that application of organic substances decreased the total abscission percentage plant ${ }^{-1}$ compared to untreated plants. The combined treatment of compost tea and humic acid significantly produced the lowest percentage compared to the application of them individually or untreated plants in both seasons. Hormones are known to influence plant growth and development and regulate the flowering and pod setting. The generally accepted model is that a basipetal IAA flux through the abscission zone of flower or pod prevents abscission by rendering the abscission zone insensitive to ethylene (Meir et al., 2010). Prevention of abscission has been found to require a continuous and constant polar supply of auxin to the abscission zone, then cell separation is inhibited and abscission does not occur (Taylor and Whitelaw, 2001). If the source of IAA is removed, the abscission zone becomes sensitized to the action of ethylene and abscission commences. The highest concentration of IAA in treated plants with humic and/or compost tea during flowering period is probably a major factor in counteract to abscission. The critical role of endogenous phytohormones in the formation and abortion of reproductive organs was clearly recognized by Ibrahim et al. (1995) and Meir et al. (2010).

\section{Yield and its components}

Data presented in Table (6) indicated that plant faba bean seed yield components, i.e. number of pods plant $^{-1}, 100$-seed weight were significantly increased by the addition of organic amendments during the two growing seasons compared to untreated plants. The highest mean values were obtained from plants received compost tea + humic acid. Meanwhile, seeds number pod $^{-1}$ showed no-significant variation to organic substances application during both seasons. One of the most important factors causing reduction in yield of faba bean plants is the abscission of flowers and/or pods of plants (Ibrahim et al., 1995). The yield loss is due primarily to a decrease in pod number plant ${ }^{-1}$. In this concern, Liu et al. (2003) mentioned that increases in ABA content at critical pod developmental stage (3-5 days after anthesis) contribute to pod abortion. These findings suggested that organic amendments supplies to soil are able to accelerate pod development in plants with high source/sink ratios.

Table 6. Yield and its components of faba bean as influenced by organic substances application.

\begin{tabular}{lllllll}
\hline \multirow{2}{*}{ Organic substances } & $\begin{array}{c}\text { Pods number } \\
\text { plant }^{-1}\end{array}$ & $\begin{array}{c}\text { Seeds number } \\
\text { pod }^{-1}\end{array}$ & $\begin{array}{c}\text { 100-seed } \\
\text { weight }(\mathrm{g} .)\end{array}$ & $\begin{array}{c}\text { Seed yield } \\
\text { plant }^{-1}(\mathrm{~g} .)\end{array}$ & $\begin{array}{c}\text { Seed yield } \\
\text { fed }^{-1}(\mathrm{~kg})\end{array}$ & $\begin{array}{c}\text { Straw yield } \\
\text { fed }^{-1}\left(\mathrm{~kg}^{2}\right.\end{array}$ \\
\cline { 2 - 7 } & & & \multicolumn{2}{c}{$2012 / 2013$} & & \\
\hline Control & $17.25 \mathrm{c}$ & $3.18 \mathrm{a}$ & $65.14 \mathrm{~b}$ & $32.04 \mathrm{c}$ & $2516.8 \mathrm{~d}$ & $3156.2 \mathrm{~d}$ \\
Compost tea (CT) & $21.43 \mathrm{ab}$ & $3.40 \mathrm{a}$ & $68.54 \mathrm{a}$ & $35.78 \mathrm{~b}$ & $2697.6 \mathrm{bc}$ & $3521.8 \mathrm{bc}$ \\
Fulvic acid (FA) & $20.25 \mathrm{~b}$ & $3.25 \mathrm{a}$ & $67.27 \mathrm{ab}$ & $34.93 \mathrm{~b}$ & $2598.7 \mathrm{~cd}$ & $3441.4 \mathrm{c}$ \\
Humic acid (HA) & $22.08 \mathrm{ab}$ & $3.68 \mathrm{a}$ & $69.12 \mathrm{a}$ & $38.66 \mathrm{a}$ & $2773.2 \mathrm{~b}$ & $3648.7 \mathrm{~b}$ \\
CT + FA & $21.65 \mathrm{ab}$ & $3.58 \mathrm{a}$ & $68.21 \mathrm{a}$ & $37.37 \mathrm{ab}$ & $2650.8 \mathrm{c}$ & $3597.3 \mathrm{bc}$ \\
CT + HA & $23.58 \mathrm{a}$ & $3.68 \mathrm{a}$ & $69.64 \mathrm{a}$ & $40.09 \mathrm{a}$ & $2973.5 \mathrm{a}$ & $3884.6 \mathrm{a}$ \\
\hline & & & & $2013 / 2014$ & & \\
\hline Control & $16.50 \mathrm{~b}$ & $3.08 \mathrm{a}$ & $65.71 \mathrm{c}$ & $31.89 \mathrm{c}$ & $2463.6 \mathrm{~d}$ & $3312.4 \mathrm{~d}$ \\
Compost tea (CT) & $20.18 \mathrm{a}$ & $3.18 \mathrm{a}$ & $67.89 \mathrm{ab}$ & $36.64 \mathrm{~b}$ & $2731.2 \mathrm{~b}$ & $3751.3 \mathrm{~b}$ \\
Fulvic acid (FA) & $19.90 \mathrm{a}$ & $3.25 \mathrm{a}$ & $67.05 \mathrm{bc}$ & $35.68 \mathrm{~b}$ & $2618.9 \mathrm{bc}$ & $3654.1 \mathrm{bc}$ \\
Humic acid (HA) & $21.58 \mathrm{a}$ & $3.50 \mathrm{a}$ & $68.74 \mathrm{ab}$ & $37.22 \mathrm{~b}$ & $2698.4 \mathrm{bc}$ & $3751.7 \mathrm{~b}$ \\
CT + FA & $20.08 \mathrm{a}$ & $3.50 \mathrm{a}$ & $67.81 \mathrm{ab}$ & $35.47 \mathrm{~b}$ & $2584.1 \mathrm{~cd}$ & $3562.4 \mathrm{c}$ \\
CT + HA & $22.15 \mathrm{a}$ & $3.58 \mathrm{a}$ & $69.34 \mathrm{a}$ & $39.73 \mathrm{a}$ & $2876.3 \mathrm{a}$ & $4087.3 \mathrm{a}$ \\
\hline
\end{tabular}

As an average of the two seasons, the increases in seed and straw yields fed ${ }^{-1}$ due to compost tea + humic treatment amounted to 17.46 and $23.24 \%$ more than untreated plants, respectively. Maximizing yield due to soil drench application of compost tea and humic acid can be correlated with direct and 
indirect positive effects on plant growth, nutrients availability and hormones content which, in turn, diverts more photo-assimilates towards higher number of sinks. Positive effects of organic substances on yield were previously reported by compost tea application (El-Gizawy et al., 2013), humic acid (Waqas et al., 2014) as well as compost tea and humic (Khafaga et al., 2014 and El-Sayed et al., 2015) as compared to the untreated plants.

\section{Seed chemical composition}

Concerning the effect of organic substances on seed chemical composition, results in Table (7) showed that there were significant increases in protein and carbohydrate biosynthesis. Application of compost tea + humic acid resulted in the highest values of protein percentage in the two season, while sole application of humic acid exhibited the highest values of carbohydrates in both seasons compared with other organic substances and untreated plants. Protein and carbohydrate yields $\mathrm{fed}^{-1}$ had parallel trend with seed yield $\mathrm{fed}^{-1}$. The beneficial effect of organic amendments on seed chemical compositions may be attributed to the promoting effects on nutrients uptake especially nitrogen, potassium and phosphorous (Table 4). Humic acid caused an increase in potassium percentage in leaves which had an important role in effect and synthesis of carbohydrates and its translocation and storing. Improving seed quality by application of compost tea and humic acid were recorded by Abbas (2013) and Khafaga et al. (2014).

Table 7. Chemical composition of faba bean seeds as influenced by organic substances application.

\begin{tabular}{lllll}
\hline \multirow{2}{*}{ Organic substances } & $\begin{array}{l}\text { Protein } \\
(\%)\end{array}$ & $\begin{array}{l}\text { Protein yield } \\
\text { fed }^{-1}(\mathrm{~kg})\end{array}$ & $\begin{array}{l}\text { Carbohydrate } \\
(\%)\end{array}$ & $\begin{array}{l}\text { Carbohydrate yield } \\
\mathrm{fed}^{-1}(\mathrm{~kg})\end{array}$ \\
\cline { 2 - 5 } & & & $2012 / 2013$ & \\
\hline Control & $24.13 \mathrm{~b}$ & $607.30 \mathrm{~d}$ & $57.23 \mathrm{c}$ & $1440.36 \mathrm{~d}$ \\
Compost tea (CT) & $26.13 \mathrm{a}$ & $704.88 \mathrm{~b}$ & $60.28 \mathrm{~b}$ & $1626.11 \mathrm{bc}$ \\
Fulvic acid (FA) & $25.16 \mathrm{ab}$ & $653.83 \mathrm{c}$ & $59.27 \mathrm{~b}$ & $1540.25 \mathrm{~cd}$ \\
Humic acid (HA) & $25.87 \mathrm{ab}$ & $717.43 \mathrm{~b}$ & $62.39 \mathrm{a}$ & $1730.20 \mathrm{ab}$ \\
CT + FA & $25.18 \mathrm{ab}$ & $667.47 \mathrm{c}$ & $59.86 \mathrm{~b}$ & $1586.77 \mathrm{bcd}$ \\
CT + HA & $26.22 \mathrm{a}$ & $779.65 \mathrm{a}$ & $60.41 \mathrm{~b}$ & $1796.29 \mathrm{a}$ \\
\hline & & & $2013 / 2014$ & $1436.53 \mathrm{e}$ \\
\hline Control & $25.11 \mathrm{c}$ & $618.61 \mathrm{~d}$ & $58.31 \mathrm{~b}$ & $1617.96 \mathrm{c}$ \\
Compost tea (CT) & $27.06 \mathrm{ab}$ & $739.06 \mathrm{~b}$ & $59.24 \mathrm{~b}$ & $1542.27 \mathrm{~d}$ \\
Fulvic acid (FA) & $25.73 \mathrm{bc}$ & $673.84 \mathrm{c}$ & $58.89 \mathrm{~b}$ & $1668.42 \mathrm{~b}$ \\
Humic acid (HA) & $26.52 \mathrm{ab}$ & $715.62 \mathrm{~b}$ & $61.83 \mathrm{a}$ & $1527.98 \mathrm{~d}$ \\
CT + FA & $26.12 \mathrm{bc}$ & $674.97 \mathrm{c}$ & $59.13 \mathrm{~b}$ & $1722.04 \mathrm{a}$ \\
CT + HA & $27.68 \mathrm{a}$ & $796.16 \mathrm{a}$ & $59.87 \mathrm{~b}$ & \\
\hline
\end{tabular}

\section{Conclusion}

The obtained results emphasize the potential of applying fulvic, humic and/or compost tea for increasing faba bean productivity. Organic substances has been positively effected several metabolic processes, enhancing plant growth and development via playing a major role in increasing photosynthesis, endogenous hormones, nutrients uptake and protein synthesis. Regular use of organic amendments, particularly as soil drench, will reduce the need of synthetic fertilizers due to the soil and plant ability to make better use of them. The advantages of such substances are related to their uses for safe food production in sustainable agricultural development systems. It could be concluded that application of compost tea combined with humic acid was the best management system for increasing faba bean yield and quality improvement under the circumstances of this study.

\section{References}

Abbas, Salwa M. (2013). The influence of biostimulants on the growth and on the biochemical composition of Vicia faba cv. Giza 3 beans. Romanian Biotechnological Letters, 18(2): 8061-8068.

Ahmed, A.H.; M.R. Nesiem, A.M. Hewedy and H.E. Sallam (2010). Effect of some simulative compounds on growth, yield and chemical composition of snap bean plants grown under calcareous soil conditions. J. of American Sci., 6(10): 552-569.

Akinci, S.; T. Büyükkeskin, A.E. Eroğlu and B.E. Erdoğan (2009). The effect of humic acid on nutrient composition in broad bean (Vicia faba L.) roots. Notulae Scientia Biologicae, 1 (1): 8187.

Ali, Aisha H.; M.R. Shafeek, Asmaa R. Mahmoud and M. El-Desuki (2014). Effect of various levels of organic fertilizer and humic acid on the growth and roots quality of turnip plants (Brassica rapa). Current Science International, 3(1): 7-14.

AOAC (2000). Official Methods of Analysis of the Association of Official Analytical Chemist, $17^{\text {th }}$ Ed. Washington, D.C. USA

Asch, F.; M.N. Andersen, C.R. Jensen and V.O. Mogensen (2001). Ovary abscisic acid 
concentration does not induce kernel abortion in field-grown maize subjected to drought. European J. of Agron., 15, 119-129.

Badr, S. A.; G. C. Mar Tin and H.T. Har Tmann (1971). A modified method for and identification of ABA and gibberellin like substances from the olive (Olea). Physiol. Plant. , 24 (2): 191-198.

Biondi, F.A.; A. Figholia, R. Indiati and C. Izza (1994). Effects of fertilization with humic acids on soil and plant metabolism: a multidisciplinary approach. Note III: phosphorus dynamics and behavior of some plant enzymatic activities. In Humic Substances in the Global Environment and Implications on Human Health. (Ed. Senesi N \& Miano TM). Elsevier, New York, pp. 239244.

Büyükkeskin, T.; Ş. Akinci and A. E. Eroğlu (2015). Effects of humic acid on root development and nutrient uptake of Vicia faba L. (broad bean) seedlings grown under aluminum toxicity. Communications in Soil Sci. and Plant Analysis, $46 \quad$ (3): 277-292. DOI:10.1080/00103624.2014.969402

Chapman, H.D. and P.F. Pratt (1978). Methods of Analysis for Soils, Plants and Water, Division of Agricultural Sciences, University of California.

Chen, Y., M.D. Nobili and T. Aviad (2004). Stimulatory effect of humic substances on plant growth. In" Soil Organic Matter in Sustainable Agriculture".(Eds F. Magdoff, R.R. Weil), 103130, Boca Raton, FL.

Dubois, M.; K.A. Gilles, J.K. Hamilton, P.A. Robers and F. Smith (1956). Colorimetric method for determination of sugar and related substances. Analytical chemistry, 28 (3): 350-356.

Duncan, D.B. (1955). Multiple range and multiple $F$ tests. Biometrics, 11 (1): 1-42, International Biometric Society.

Edwards, C.A.; N.Q. Arancon and S. Greytak (2006). Effects of vermicompost teas on plant growth and disease. BioCycle 47, 28-31.

El-Gizawy, E.S.A.; A.A.I. Atwa, N.I.Talha and R.A.I. Mostafa (2013). Effect of compost and compost tea application on faba bean crop and some soil biological and chemical properties. J. Soil Sci. and Agric. Eng., Mansoura Univ., 4 (9): 863 - 874.

El-Sayed, Hala A.; M.M. Zaghloul , K.A.M. Nour and Rasha H. Attia (2015). Treatment of snap bean plants grown under sandy soil conditions with some natural materials and its relation to growth, yield and pod quality. J. Plant Production, Mansoura Univ., 6 (3): 395 - 421.

Enteshari, S.; M. Saadatmand and M. Pirzadeh (2012). Effect of vermicompost (cow manure) and mycorrhizal on some physiological characteristics of turnip (Brassica rapa L.) in hydroponic culture. The $1^{\text {st }}$ International and the $4^{\text {th }}$ National Congress on Recycling of Organic
Waste in Agriculture 26-27 April in Isfahan, Iran.

Hiraja, K.; T. Yokota, N. Murofushi and N. Takahashi (1972). Isolation and characterization of free gibberellins and glycosyl-esters of gibberellins in mature seeds of Phaseolus vulgaris. Agric. Biol. Chem., 36 (2): 345-347.

Homme, P.M., B. Gonzalez and J. Billard (1992). Carbohydrate content, frutane and sucrose enzyme activities in roots, stubble and leaves of rye grass (Lolium perenne L.) as affected by source/sink modification after cutting. J. of Plant $\begin{array}{lll}\text { Physiology, } & 140 & \text { (3): }\end{array}$ http://dx.doi.org/10.1016/S01761617(11)81080-1

Ibrahim, M.E.; A.E. Moftah and A.A. Gendy (1995). Growth, flowering, abscission, endogenous hormones, yield of broad bean (Vicia faba L.) as affected by tebepas and zinc. Zagazig J. Agric. Res., Vol. 22 (1): 79-104.

Jackson, M.L. (1973). Soil Chemical Analysis. Prentice Hall of India, Ltd., New Delhi, India.

Jensen, E.S.; M.B. Peoples and H. HauggaardNielsen (2010). Faba bean in cropping systems. Field Crops Research 115: 203-216. doi:10.1016/j.fcr.2009.10.008

Khafaga, E.E.E; Salwa A. Hasanin and Rania M. ElShal (2014). Effect of foliar application with ascorbic, humic acids and compost tea on nutrients content and faba bean productivity under sandy soil conditions. J. Soil Sci. and Agric. Eng., Mansoura Univ., 5 (6): 767-778.

Khaled, H. and H. A. Fawy (2011). Effect of different levels of humic acids on the nutrient content, plant growth, and soil properties under conditions of salinity. Soil \& Water Res., 6 (1): 21-29.

Litterick, A.M.; P. Wallace, C.A. Watson and M. Wood (2004). The role of uncomposted materials, composts, manures, and compost extracts in reducing pest and disease incidence and severity in sustainable temperate agricultural and horticultural crop production- review. Crit. Rev. Plant Sci., 23, 453-479.

Liu, F.; Mathias N. Andersen and Christian R. Jensen (2003). Loss of pod set caused by drought stress is associated with water status and $\mathrm{ABA}$ content of reproductive structures in soybean. Functional Plant Biology, 30: 271-280.

Meir, S.; S. Philosoph-Hadas, S. Sundaresan, K.S. V. Selvaraj, S. Burd, R. Ophir, B. Kochanek, M.S. Reid, C. Jiang and A. Lers (2010). Microarray analysis of the abscission-related transcriptome in the tomato flower abscission zone in response to auxin depletion. Plant Physiology, 154: 19291956.

Naidu, Y.; S. Meon, J. Kadir and Y. Siddiqui (2010). Microbial starter for the enhancement of biological activity of compost tea. Int. J. Agric. Biol., 12 (1): 51-56. 
Nardi, S.; D. Pizzeghello, A. Muscolo and A. Vianello (2002). Physiological effects of humic substances on higher plants. Soil Biology \& Biochemistry 34: 1527-1536.

Navarrete J. M.; V. M. Urbina, T. Martínez and L. Cabrera (2004). Role of fulvic acids for transporting and fixing phosphate and iron ions in bean plants by radiotracer technique. J. of Radioanalytical and Nuclear Chemistry, 259: 311-314.

Osman E.A.M.; A.A. EL- Masry and K.A. Khatab (2013). Effect of nitrogen fertilizer sources and foliar spray of humic and/or fulvic acids on yield and quality of rice plants. Advances in Applied Science Research, 4(4):174-183.

Pant, A.; T.J.K. Radovich, N.V. Hue and N.Q. Arancon (2011). Effects of vermicompost tea (aqueous extract) on pak choi yield, quality, and on soil biological properties. Compost Science \& Utilization, 19 (4): 279-292.

Pant, A.b.; T.J.K. Radovich, N.V. Hue and R.E. Paull (2012). Biochemical properties of compost tea associated with compost quality and effects on pak choi growth. Scientia Horticulturae, 148: 138-146. http://dx.doi.org/10.1016/j.scienta.2012.09.019

Russo, R.O. and G.P. Berlyn (1990). The use of organic biostimulants to help low input sustainable agriculture. J. of Sustainable Agriculture 1: 19-42.

Sarhan, T. Z.; G. H. Mohammad and J. A. Teli (2011). Effects of humic acid and bread yeast on growth and yield of eggplant (Solanum melongena L.). J. of Agric. Sci. and Tech., B (1): 1091-1096.
Snedecor, G.W. and W.G. Cochran (1980). Statistical Methods, $7^{\text {th }}$ Ed. The Iowa State Univ. Press, Ames. Iowa, USA.

Steponënienë, L.; S. Tautkus and R. Kazlauskas (2003). Determination of zinc in plants and grains by atomic absorption spectrometry. Chemija, 14 (2): 99-102.

Stratton, M.L., A.V. Barker, and J.E. Rechcigl. (1995). Compost. pp. 249- 310. In: J.E. Rechcigl (Ed.). Soil Amendments and Environmental Quality. Lewis Publishers, London.

Tan, K.H. (2003). Humic Matter in Soil and Environment. Principles and Controversies. Marcel Dekker Inc., New York, USA, P. 154278

Taylor, J.E. and C.A. Whitelaw (2001). Signals in abscission. New Phytologist, 151 (2): 323-339

Tognetti, C.; F. Laos, M.J. Mazzarino and M.T. Hernandez (2005). Composting vs vermicomposting: a comparison of end product quality. Compost Sci. Util. 13: 6-13.

Vanitha, K. and S. Mohandass (2014). Effect of humic acid on plant growth characters and seed yield of drip fertigated aerobic rice (Oryza sativa L.). J. The Bioscan. 9 (1): 45 - 50.

Waqas, M.; B. Ahmad, M. Arif, F. Munsif, A. Khan, M. Amin, S. Kang, Y. Kim and I. Lee (2014). Evaluation of humic acid application methods for yield and yield components of mungbean. American J. of Plant Sci., 5: 2269-2276. http://dx.doi.org/10.4236/ajps.2014.515241

Wettstein, D.V. (1957). Chlorophyll Totale und der Submikroskopische Form- wechsel der Plastiden. Experimental Cell. Res., 12: 427-433. 
دور المركبات الدبالية وشاي الكمبوست فى تحسين محتوى الهرمونات الداخلية والتزهير والمحصول ومكوناته فى الفول البلدى

$$
\text { قسم المحاصيل - كلية الزراعة - جامعة عحم على المنوفية - مصر }
$$

\section{الملخص العربي}

لا يزال إنتاج الفول البلاى في مصر محدوداً ولا يفى بمواجهة الزيادة المستمرة للاستهلاك من محصول البذور لنقص المساحة المنزرعة وقلة

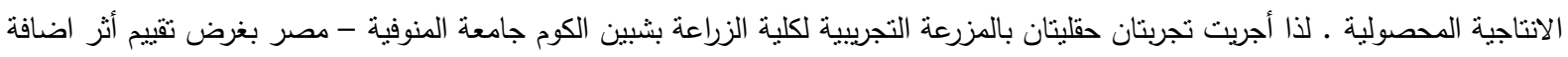
بعض المركبات العضوية (حمض الفولفيك ، حمض الهيوميك ، شاى الكمبوست) بصورة منفردة أو مخلوطة على صفات النمو الخضرى وامنصاص العناصر الغذائية ومحتوى الهرمونات الداخلية و طبيعة التزهير وانتاجية وجودة الفول البلدى (صنف جيزة 3 محسن) خلال موسمي

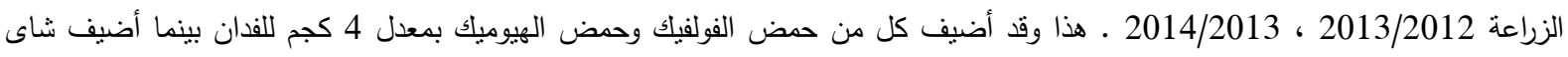

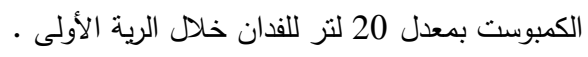
أوضحت النتائج أن اضافة المركبات العضوية سواء بصورة منفردة أو مخلوطة كان له أثز فعال فى تحسين صفات النمو الخضرى (ارتفاع

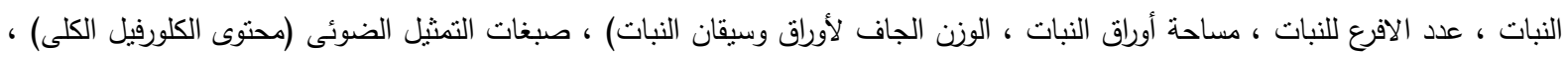

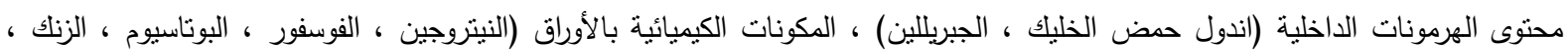

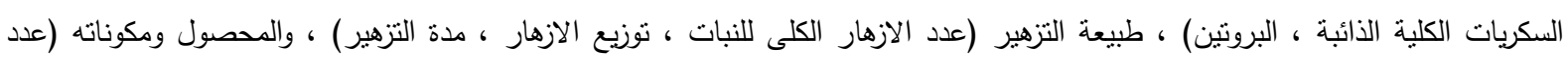

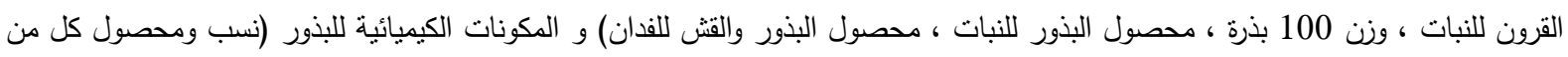
البروتين والكربوهيدرات) وذلك مقارنة بالنبانات غير المعاملة . وقد أظهرت المعاملة بشاي الكمبوست مقترنا بحمض الهيومك تفوقاً ملحوظاً على بقية المواد العضوية الأخرى فى انتاج أعلى قيم للصفات

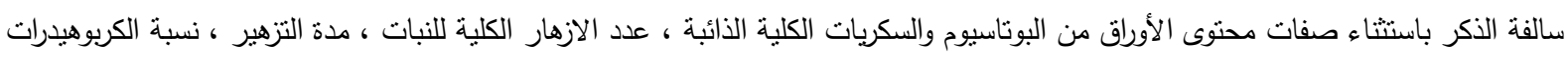

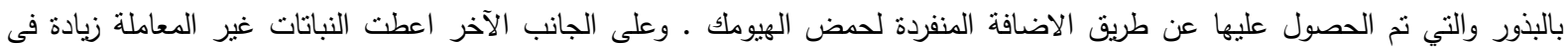

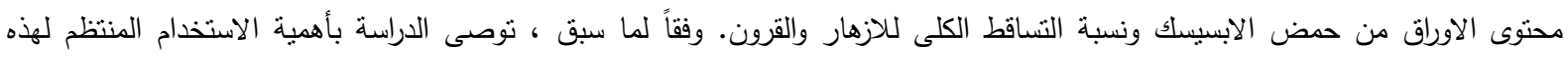

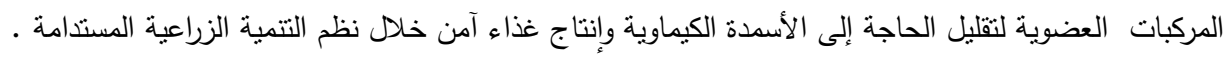

